Texas City Ship Channel Deepening Study, Hydrodynamic Model

Lisa M. Lee, Jennifer N. Tate, and R. C. Berger

August 2005

US Army Corps of Engineers

Engineer Research and Development Center

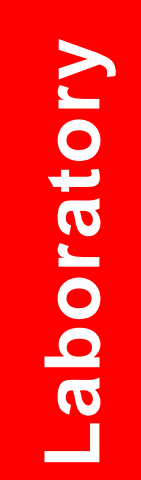


ERDC/CHL TR-05-6

August 2005

\section{Texas City Ship Channel Deepening Study, Hydrodynamic Model}

Lisa M. Lee, Jennifer N. Tate, R. C. Berger

Coastal and Hydraulics Laboratory

U.S. Army Engineer Research and Development Center

3909 Halls Ferry Road

Vicksburg, MS 39180-6199

Final report

Approved for public release; distribution is unlimited

Prepared for U.S. Army Engineer District, Galveston

Galveston, TX 77553-1229 


\begin{abstract}
The U.S. Army Engineer District, Galveston (SWG), is proposing to deepen the Texas City Ship Channel as well as add a turning basin and berthing area. The Texas City Ship Channel is approximately 6.75 miles long and extends from Bolivar Roads at the entrance of Galveston Bay from the Gulf of Mexico to the turning basin at Texas City. The Houston Ship Channel and the Texas City Ship Channel provide access to the deep-water ports along the bay. The study area includes the entire bay area and these deep-draft channels. The Texas City Ship Channel is currently $40 \mathrm{ft}$ deep at mean low water $(\mathrm{mlw})$ and $400 \mathrm{ft}$ wide. The proposed depth is $45 \mathrm{ft}$ and the width will remain the same. The added turning basin measures $700 \mathrm{ft}$ across the top, with the berthing area 6,000 by $825 \mathrm{ft}$. A ship simulator study is being conducted to assess the impact of these modifications on the ability of shipping to use the port. This particular study is used to determine and provide maximum ebb and flood currents for the ship simulator study.
\end{abstract}

DISCLAIMER: The contents of this report are not to be used for advertising, publication, or promotional purposes. Citation of trade names does not constitute an official endorsement or approval of the use of such commercial products. All product names and trademarks cited are the property of their respective owners. The findings of this report are not to be construed as an official Department of the Army position unless so designated by other authorized documents. 


\section{Contents}

Conversion Factors, Non-SI to SI Units of Measurement.................................. v

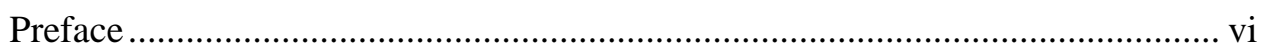

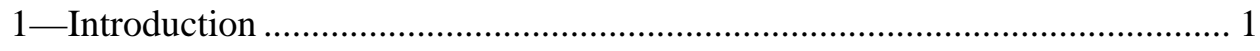

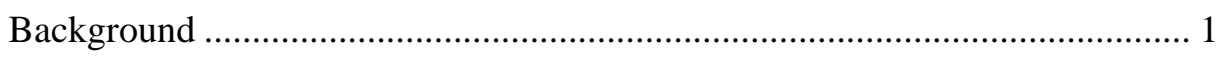

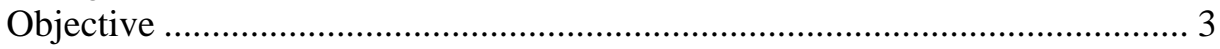

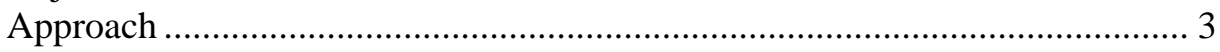

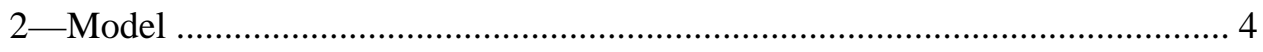

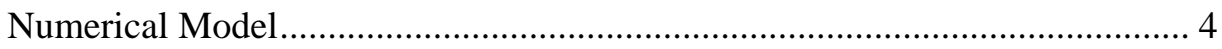

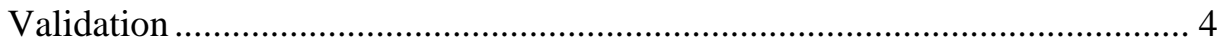

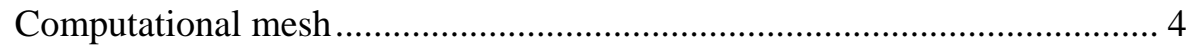

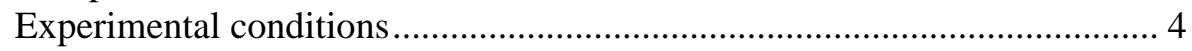

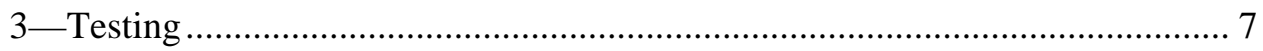

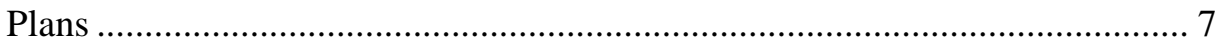

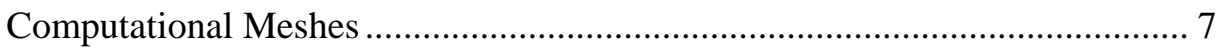

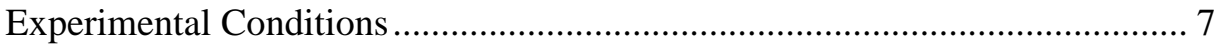

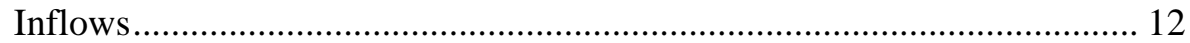

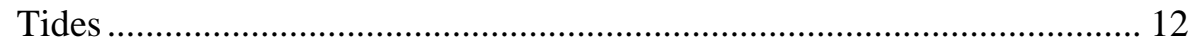

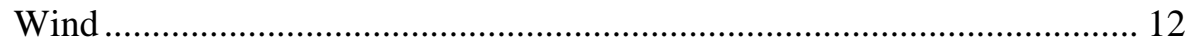

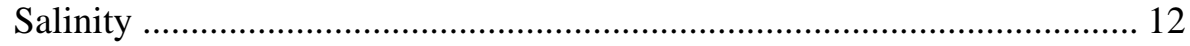

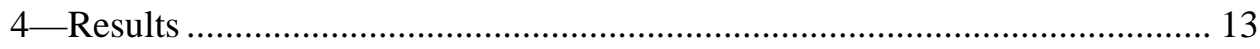

5-Summary and Conclusions ..................................................................... 20

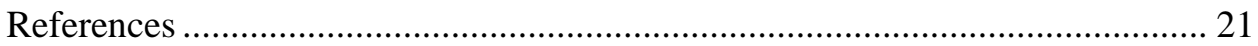

SF 298

\section{List of Figures}

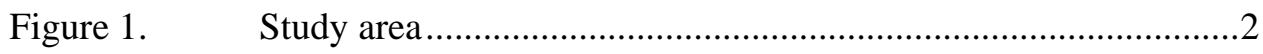

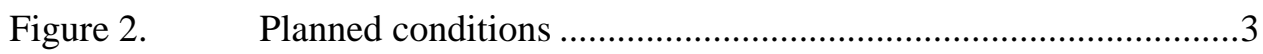


Figure 3. Mesh for existing conditions ................................................... 5

Figure 4. Detail of Texas City Channel ...................................................6

Figure 5. Cross-sections at Station A …...............................................

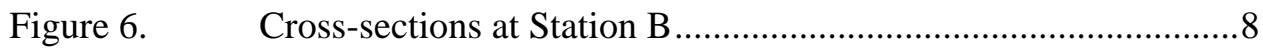

Figure 7. Mesh for existing conditions .................................................... 9

Figure 8. $\quad$ Mesh for planned conditions …................................................10

Figure 9. Close up view of Texas City Ship Channel for existing conditions ............................................................................11

Figure 10. Close up view of Texas City Ship Channel for planned

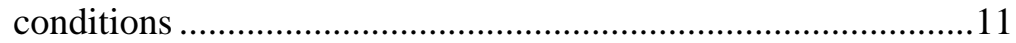

Figure 11. Maximum ebb for existing conditions......................................14

Figure 12. Maximum ebb for planned conditions.......................................15

Figure 13. Maximum flood for existing conditions ...................................16

Figure 14. Maximum flood for planned conditions .....................................17

Figure 15. Difference (Plan-Base) in velocity magnitude at maximum flood conditions ........................................................................18

Figure 16. Difference (Plan-Base) in velocity magnitude at maximum

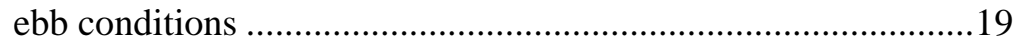




\section{Conversion Factors, Non-SI to SI Units of Measurement}

Non-SI units of measurement used in this report can be converted to SI units as follows:

\begin{tabular}{||l|l|l||}
\hline \hline Multiply & By & To Obtain \\
\hline \hline feet & 0.3048 & meters \\
\hline miles (U.S. statute) & 1.609347 & kilometers \\
\hline
\end{tabular}




\section{Preface}

This report represents the results of a numerical model investigation used to study the impacts on the present hydrodynamics of the Texas City Ship Channel from a proposed deepening and added turning basin.

This investigation was conducted from August 2004 through May 2005 at the U.S. Army Engineer Research and Development Center (ERDC), Vicksburg, MS, by Ms. Lisa M. Lee and Dr. R. C. Berger of the Coastal and Hydraulics Laboratory (CHL), and Mr. Ishaq Syed of the U.S. Army Engineer District, Galveston. Funding was provided by the Galveston District.

This study is intended to provide currents for use in a ship simulator study to be performed at ERDC, Vicksburg, MS, with Mr. Gary Lynch, CHL, acting as the principal investigator.

The work was performed under the general direction of Dr. Robert T. McAdory, Chief, Estuarine Engineering Branch, CHL, and Mr. Thomas Richardson, Director, CHL.

At the time of publication of this report, COL James R. Rowan, EN, was Commander and Executive Director of ERDC. Dr. James R. Houston was Director. 


\section{Introduction}

\section{Background}

The U.S. Army Engineer District, Galveston (SWG), is proposing to deepen the Texas City Ship Channel as well as add a turning basin and berthing area. The Texas City Ship Channel is approximately 6.75 miles $^{1}$ long and extends from Bolivar Roads at the entrance of Galveston Bay from the Gulf of Mexico to the turning basin at Texas City. The Houston Ship Channel and the Texas City Ship Channel provide access to the deep-water ports along the bay. The study area shown in Figure 1 includes the entire bay area and these deep-draft channels. The Texas City Ship Channel is presently $40 \mathrm{ft}$ deep at mean low water (mlw) and $400 \mathrm{ft}$ wide. The elevation of mean low water at Morgan Point is $0.17 \mathrm{~m}$ $(0.56 \mathrm{ft})$ and is $0.21 \mathrm{~m}(0.70 \mathrm{ft})$ at Pleasure Pier below mean tide level. The proposed depth is $45 \mathrm{ft}$ and the width will remain the same. The added turning basin measures $700 \mathrm{ft}$ across the top with the berthing area 6,000 by $825 \mathrm{ft}$. See Figure 2 for details of the planned conditions. A ship simulator study is being conducted to assess the impact of these modifications on the ability of shipping to use the port. This particular study is used to provide currents for the ship simulator study.

A model consists of the mesh, the data, and the hydrodynamic code. The mesh represents the spatial grid and bathymetry and the data include the boundary conditions and the forcing data. The Galveston model used in this study was originally developed to study the enlargement of the Houston Ship Channel in the early to mid 1990s (Berger et al. 1995). The model was then updated in 2002 to study the effects of adding barge lanes along the Houston Ship Channel (Carrillo et al. 2002). The grid, referred to as the "As Built" conditions, was used as the starting point for this study. This included a Houston Ship Channel that had authorized dimensions of $45 \mathrm{ft}$ deep and $530 \mathrm{ft}$ wide. However, the "As Built" conditions had a channel that was typically about $49 \mathrm{ft}$ deep. This included advance maintenance and allowable over-depth dredging. The "As Built” depths were used in the numerical model grid. This grid was then modified to include the Texas City Ship Channel in more detail. The hydrodynamic code used is TABS-MDS.

1 A table of factors for converting non-SI units of measurement to SI units is found on page v. 


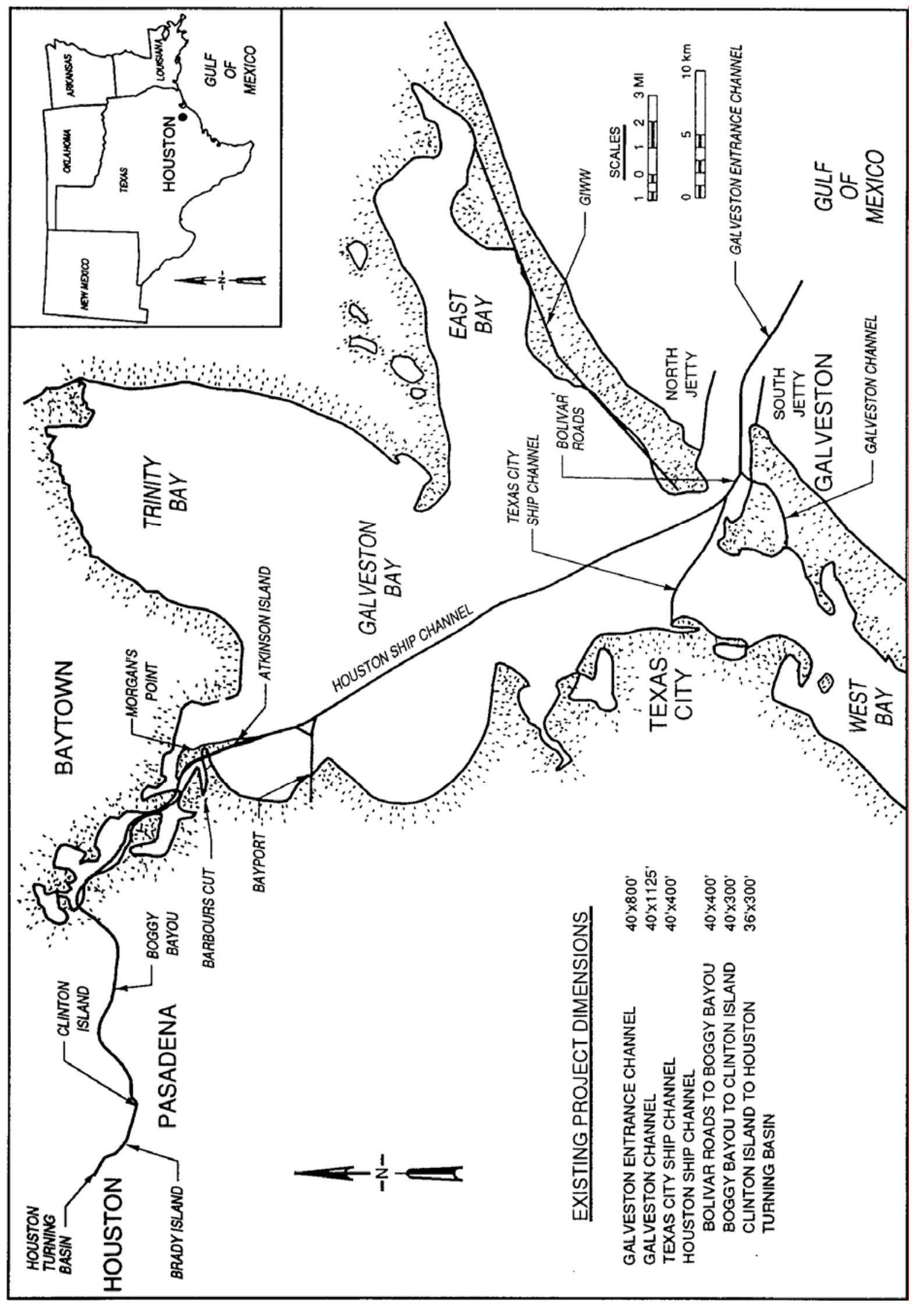

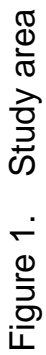




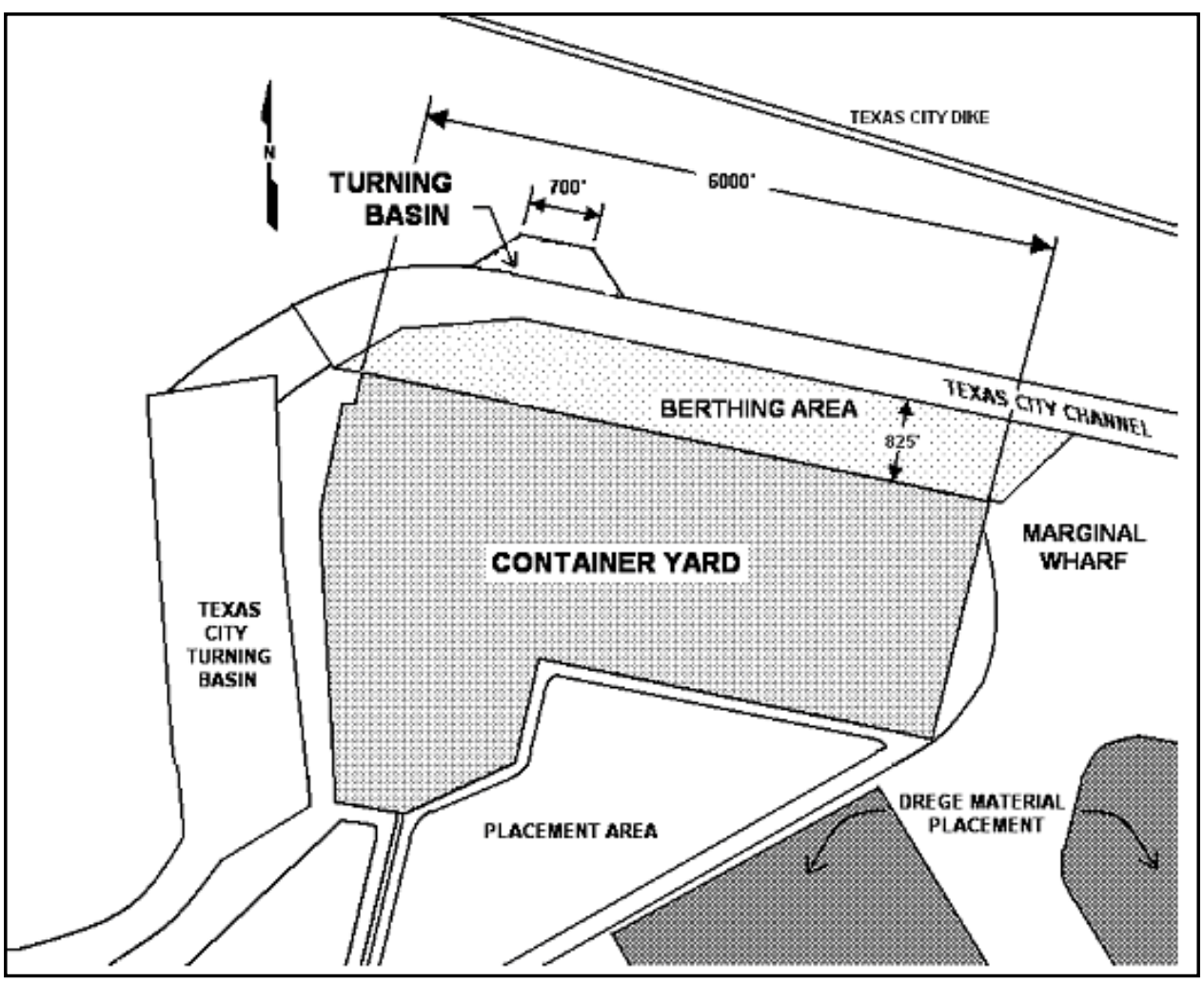

Figure 2. Planned conditions

\section{Objective}

SWG will perform a ship simulator study at the U.S. Army Engineer Research and Development Center, Coastal and Hydraulics Laboratory (ERDCCHL). The hydrodynamic currents used in the simulator analysis of the existing and plan conditions will be calculated using the models discussed here. The goal for ERDC-CHL is to provide currents for both the existing and plan conditions to be used in the ship simulator study at ERDC-CHL.

\section{Approach}

The tasks conducted to fulfill this objective are:

a. Update the mesh to fully include the Texas City Ship Channel.

$b$. Provide a short check of the verification.

c. Modify the Texas City Ship Channel to reflect the planned conditions.

d. Run each mesh for a month and identify the time of maximum flood and ebb and provide these currents to the ship simulator. 


\section{Model}

\section{Numerical Model}

The numerical model used for this study is TABS-MDS. This is a 3-D finite element code originally developed by Dr. Ian King of Resource Management Associates and extensively modified at ERDC-CHL. It models 3-D hydrodynamics and salt transport, accounting for unsteady river inflows, tides, wind effects, and density-driven circulation. It has been widely used by ERDC to model 3-D hydrodynamics and salinity at numerous locations, including Galveston Bay, TX.

\section{Validation}

This model has been verified and checked in previous studies. A recheck of the velocity and tides was conducted in this study. The modified mesh was run with the same boundary conditions and code as used in the previous study (Carrillo et al. 2002). The model was checked to verify that the same range and frequency of velocity and water surface elevations were being computed. A brief discussion of the experimental conditions follows. For more details see Berger et al. (1995a).

\section{Computational mesh}

The mesh used for this quick recheck is shown in Figure 3. The mesh consists of 13,808 nodes and 4,777 elements. The mesh was expanded to fully include the Texas City Ship Channel. The more refined mesh along Texas City is included in Figure 4.

\section{Experimental conditions}

The data used to drive the model tide were the National Ocean Service/ National Oceanic and Atmospheric Administration (NOS/NOAA) sta 877-1510. Pleasure Pier tide data shifted forward $1.31 \mathrm{hr}$ to account for the model boundary approximately 26 miles offshore. The data were filtered to remove signals with a period of less than $3 \mathrm{hr}$. The salinity at the boundary was estimated by using the published averages supplied by Cochrane and Kelly (1986). The wind data were 


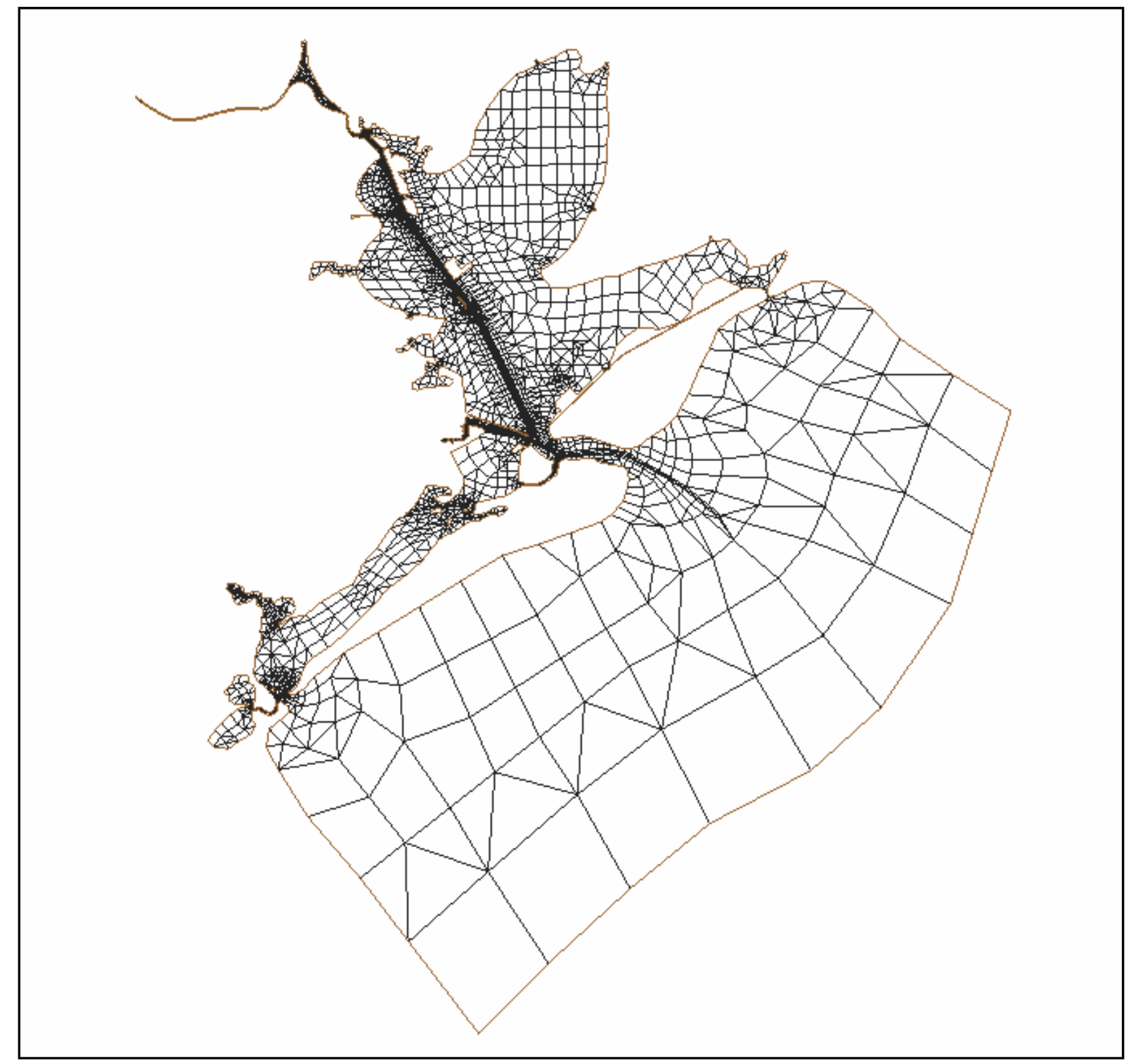

Figure 3. Mesh for existing conditions

provided by two sources. ERDC established a meteorological station for a period from 19 July 1990 to 15 January 1991. The National Weather Service data at Houston International Airport were also obtained for this period. A correlation was derived between the National Weather Service and ERDC data, so that readings at Houston Intercontinental could be used for Galveston Bay (see Berger et al. (1995)).

The water-surface elevations and current velocities were calculated every $0.5 \mathrm{hr}$. The numerical model was run for 21 days starting January 1990. The amount of simulation time needed is enough to complete a full spring-neap tidal sequence, plus the spin-up time to remove initial conditions. For salinity 


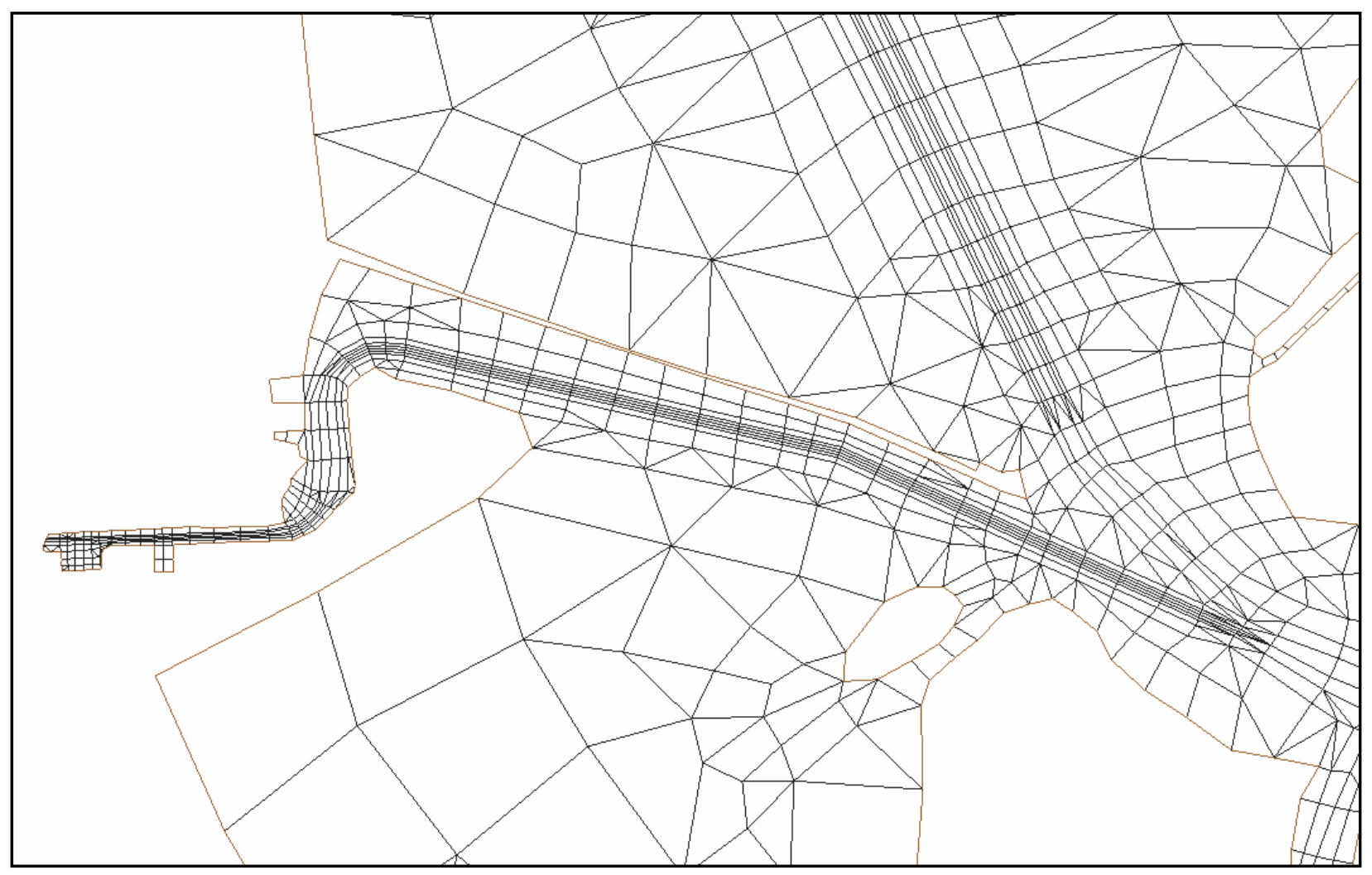

Figure 4. Detail of Texas City Channel

simulations, the spin-up time is quite large, often months. However, for hydrodynamics alone, this time is typically only a tidal cycle or two. The model only needed to run long enough to identify when the maximum flood and ebb conditions occurred. 


\section{Testing}

\section{Plans}

Two conditions were run in this study: for the existing channel and planned deepened channel. The depth of the Texas City Ship Channel for the existing conditions was determined from channel survey data. The Galveston District provided these data. The survey data indicated that the channel was closer to $46 \mathrm{ft}$ deep rather than the specified depth of $40 \mathrm{ft}$. This difference is mostly attributable to advanced maintenance $(2 \mathrm{ft})$, overdraft $(2 \mathrm{ft})$, and scouring at some locations. The depth for the planned conditions was set to be $49 \mathrm{ft}$ ( $45 \mathrm{ft}$ planned depth $+3 \mathrm{ft}$ advanced maintenance $+1 \mathrm{ft}$ overdraft). The turning basin and the berthing area were also set to this depth. Figures 5 and 6 compare the crosssection between the two modeled conditions and the survey data. These comparisons were done at the locations indicated in Figures 9 and 10. Section A includes the berthing area that has been added in the planned conditions. Section B shows a typical cross section of the channel away from the turning basin or berthing area.

\section{Computational Meshes}

Figures 7 and 8 show the planform view of the computational meshes used. The number of nodes and elements for each mesh is given in Table 1. Figures 9 and 10 show close up views of the Texas City Channel so that the changes in the mesh can be seen. The areas that are shown in gray are 3-D, the other regions are 2-D.

\section{Experimental Conditions}

Because the conditions used for this study were created for a previous study, only a brief summary is being given here. For details on these conditions see Berger et al. (1995). 


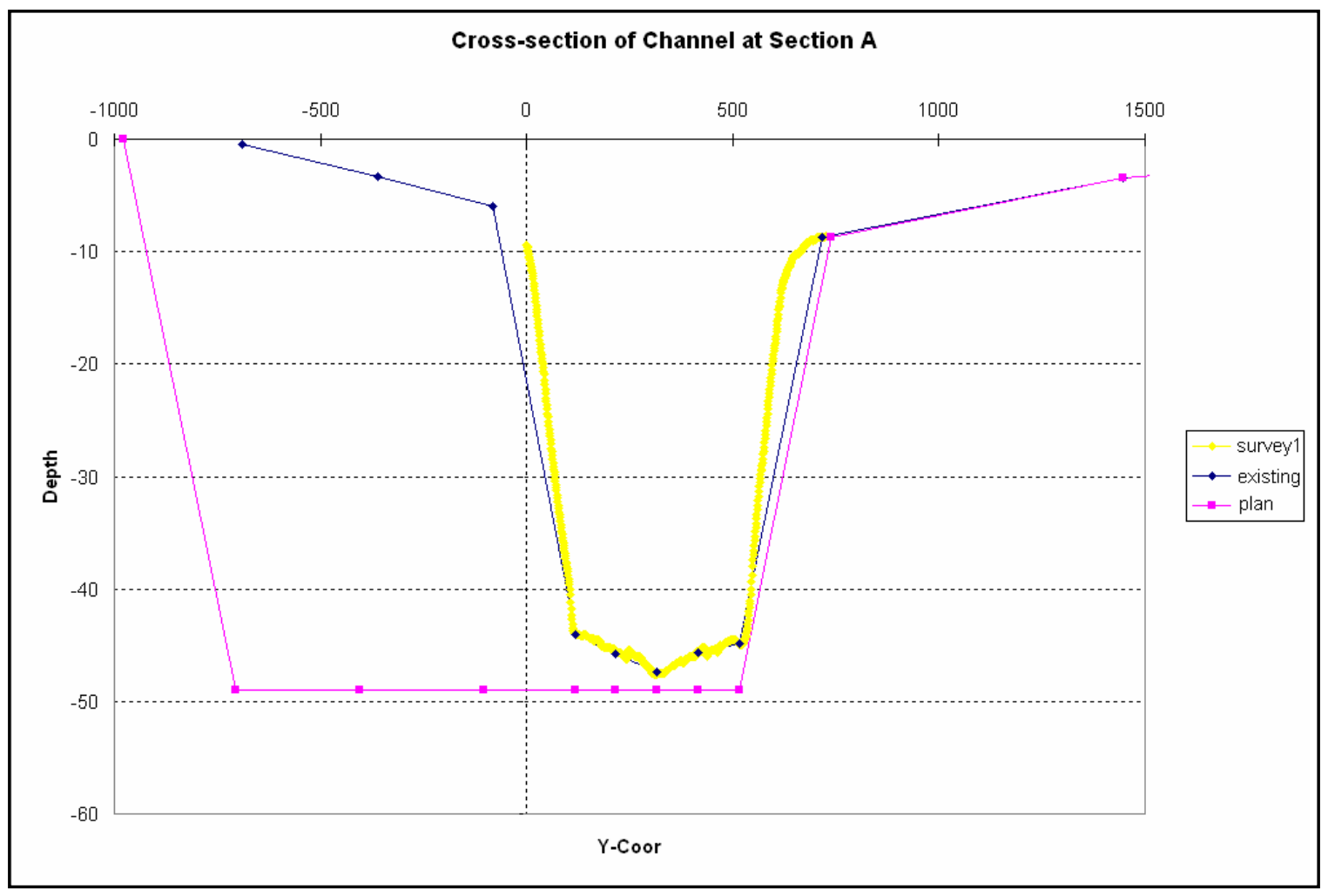

Figure 5. Cross-sections at Station A

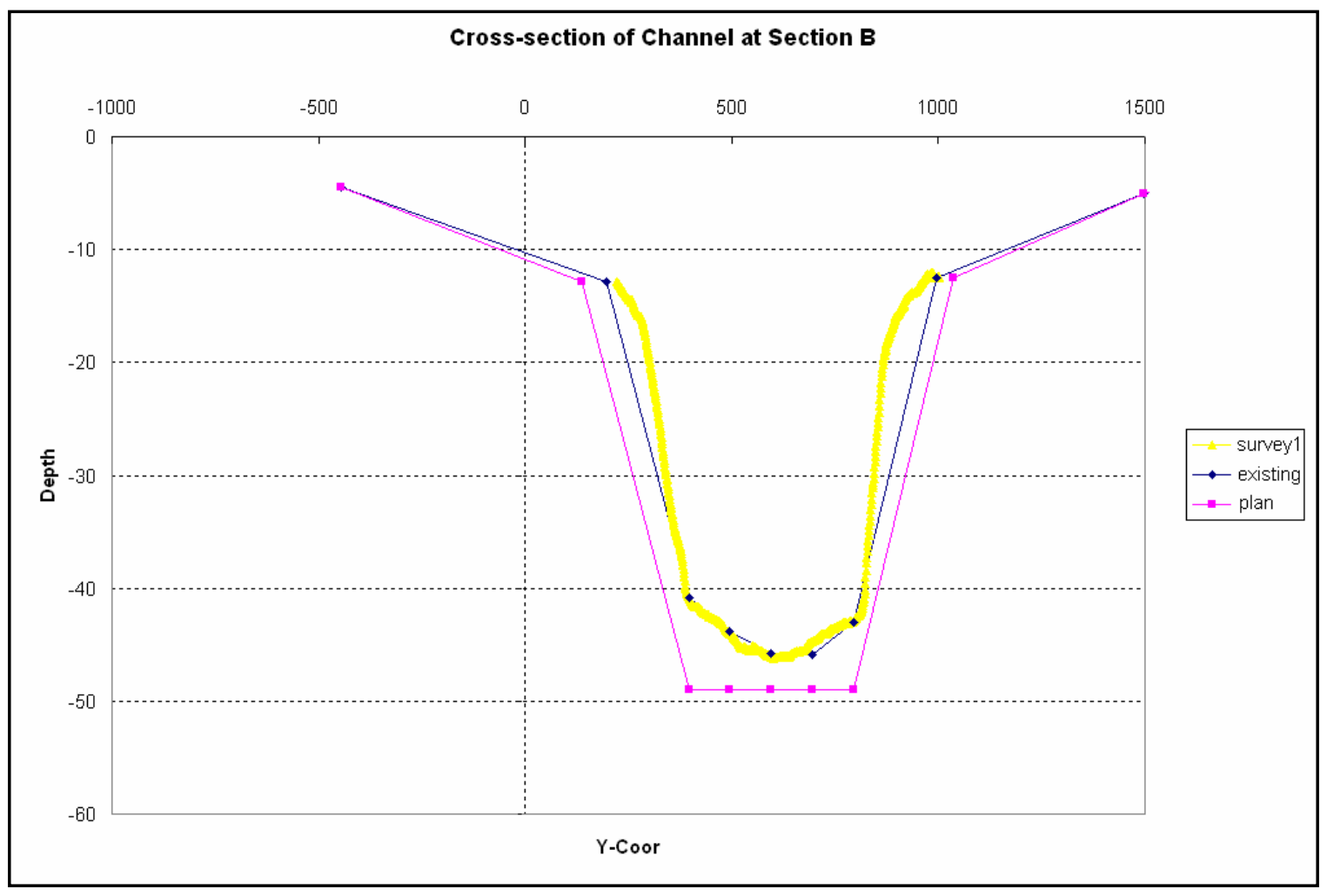

Figure 6. Cross-sections at Station B 


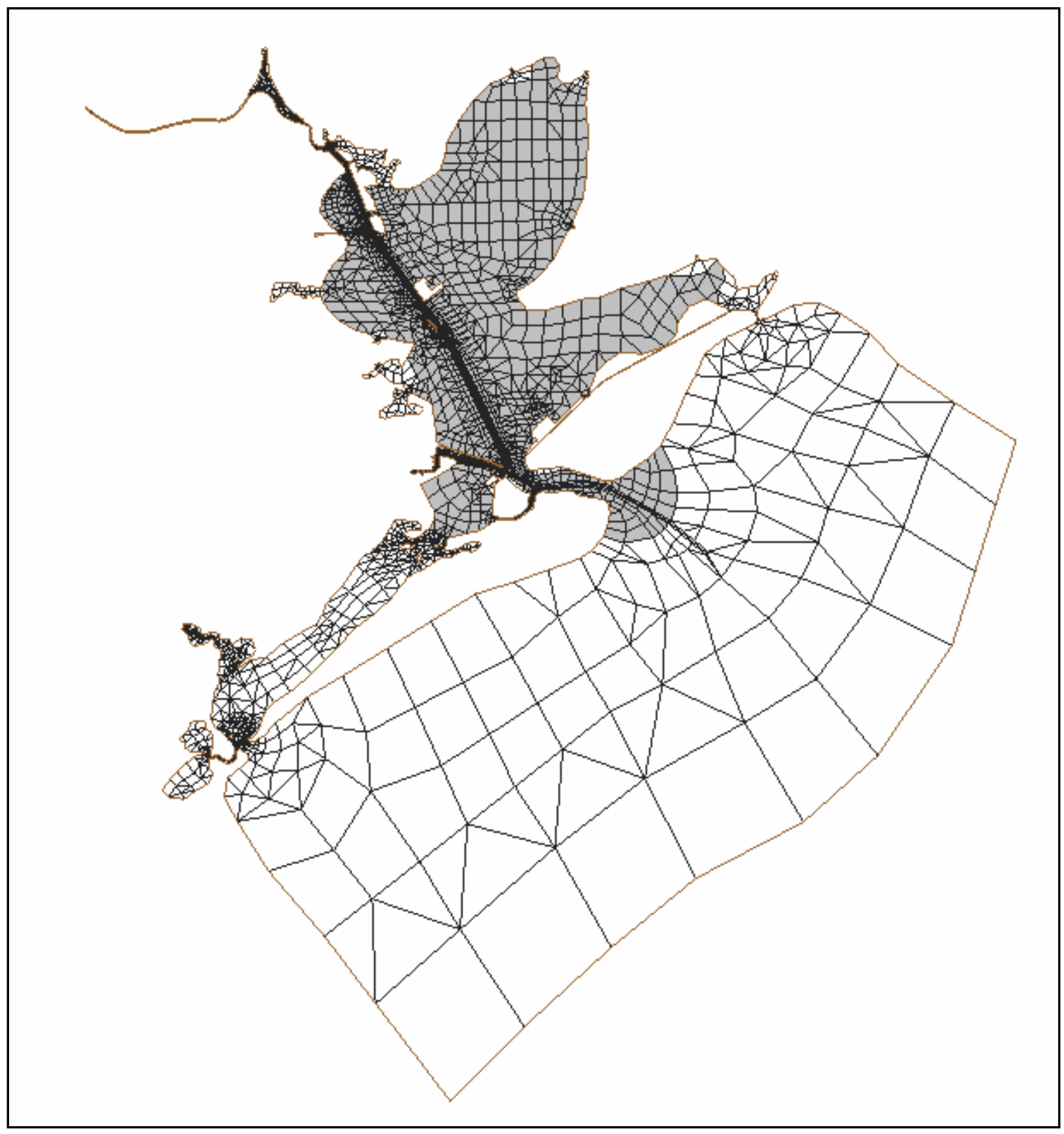

Figure 7. Mesh for existing conditions 


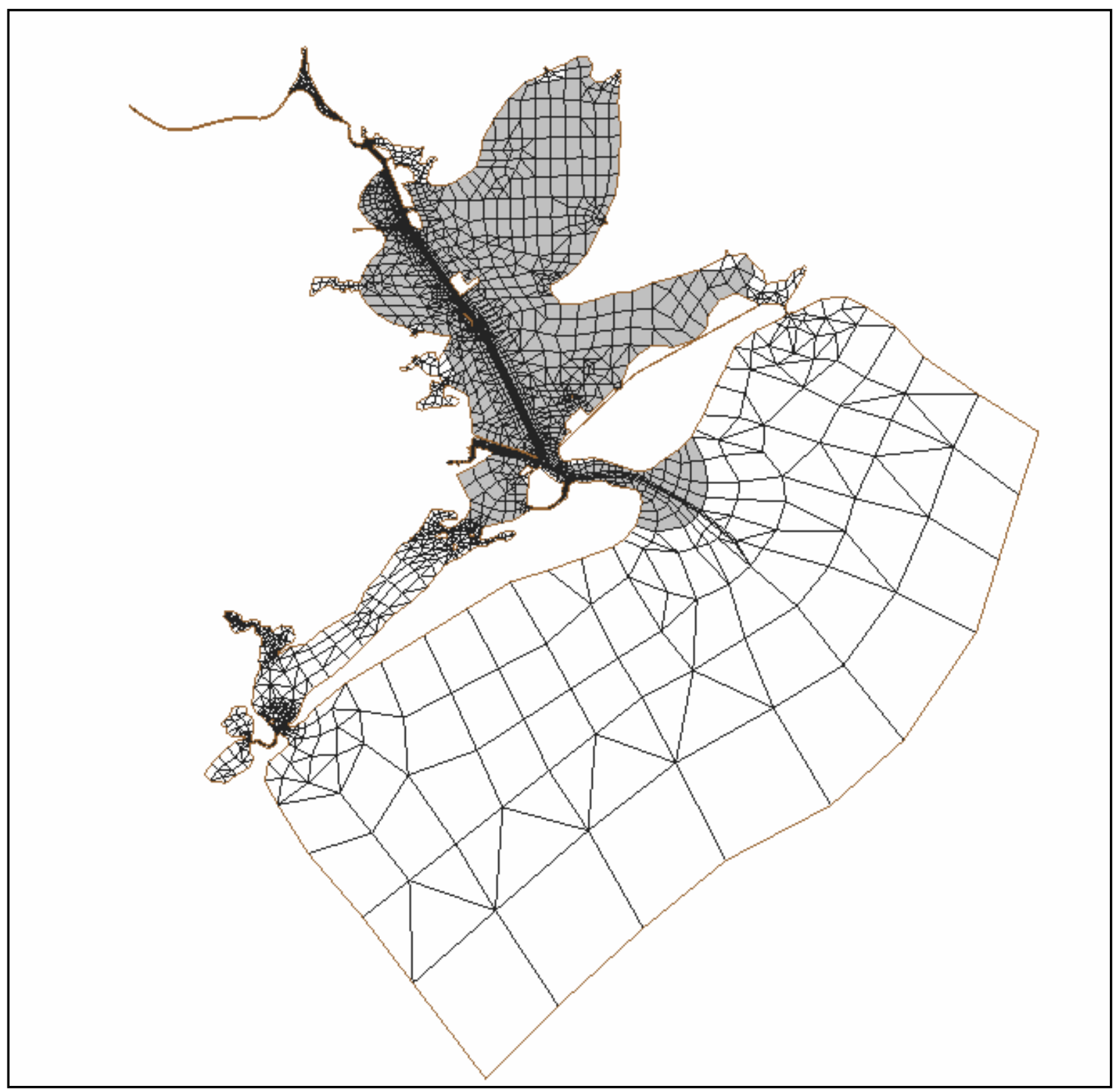

Figure 8. Mesh for planned conditions

\begin{tabular}{|l|l|l||}
\hline \hline $\begin{array}{l}\text { Table1 } \\
\text { Mesh Sizes }\end{array}$ & \multicolumn{2}{l||}{} \\
\hline \hline Mesh & Nodes & Elements \\
\hline \hline Existing & 13808 & 4777 \\
\hline Planned & 13951 & 4828 \\
\hline
\end{tabular}




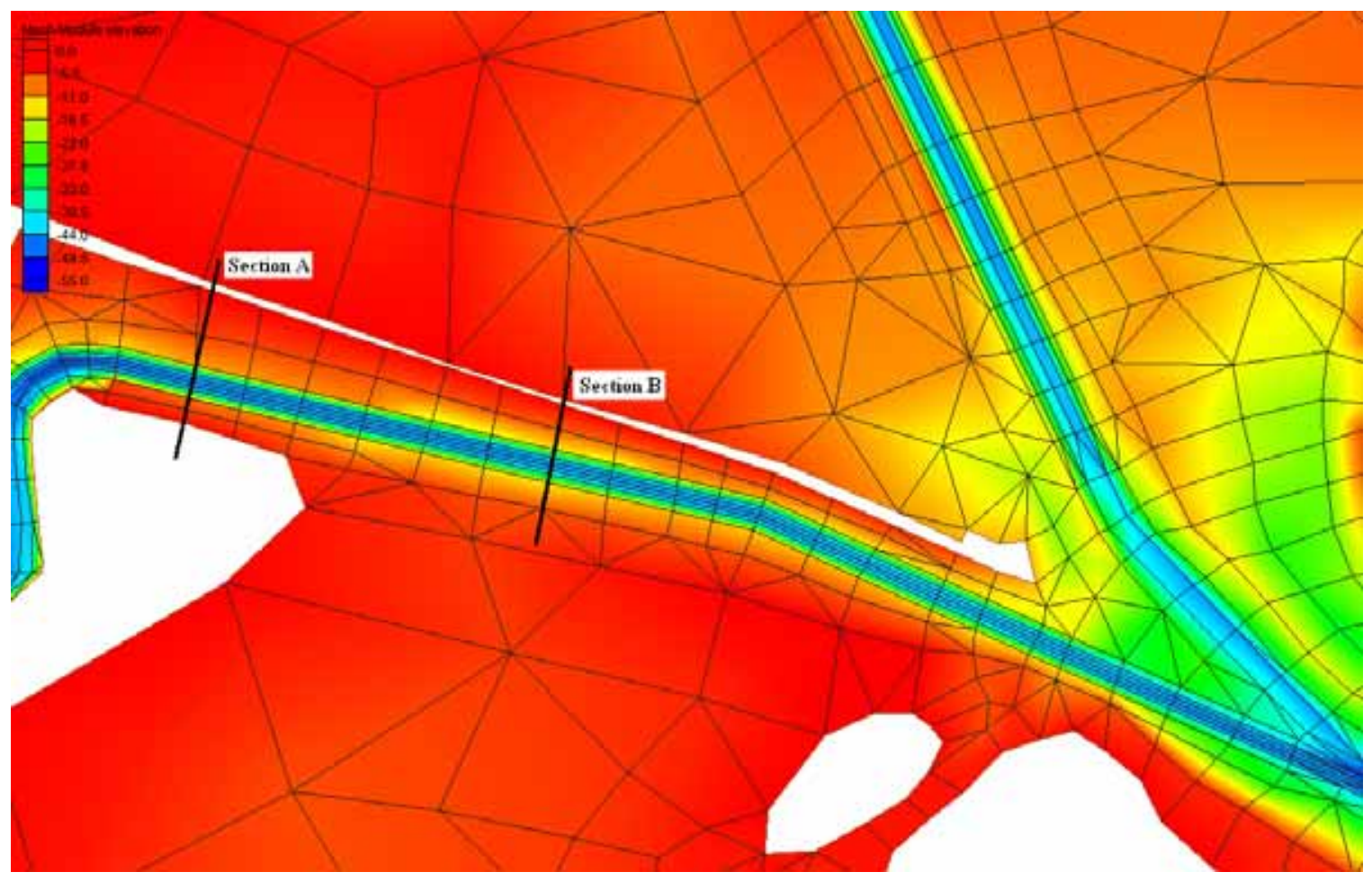

Figure 9. Close up view of Texas City Ship Channel for existing conditions

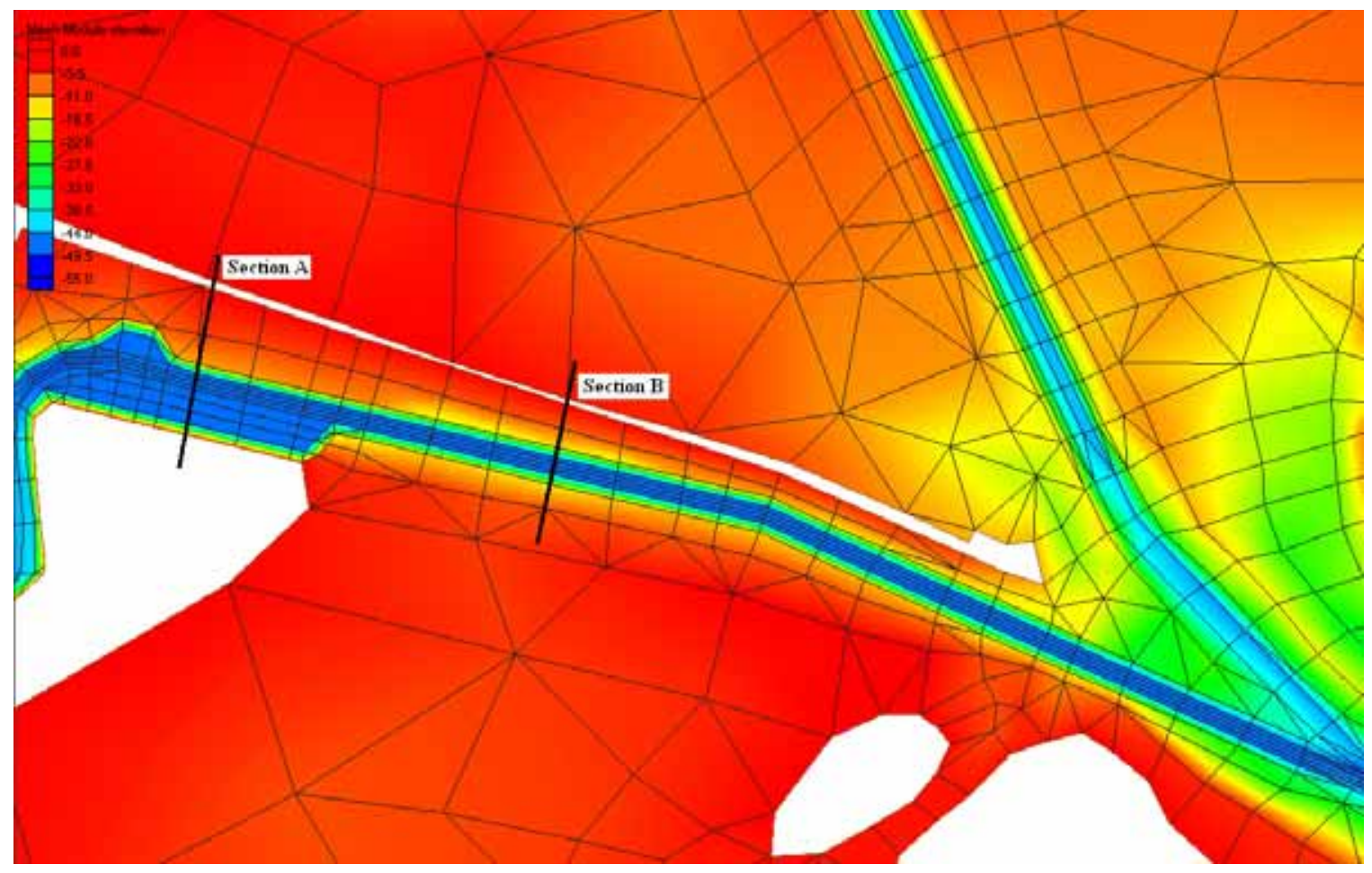

Figure 10. Close up view of Texas City Ship Channel for planned conditions 


\section{Inflows}

The "Present" low-flow hydrologic era from the previous study was again used here. In additions to the river inflows, two power plants were included in the model: the Cedar Bayou and the Robinson plants. Intake data for 1990 were used and the salinity at the intake was used as the boundary condition for the discharge.

\section{Tides}

The tidal boundary conditions were from NOS/NOAA sta 877-1510 at Pleasure Pier for 1984 . The data were shifted by $1.31 \mathrm{hr}$ to account for the model boundary being about 26 miles from Pleasure Pier. Periods of less than $3 \mathrm{hr}$ were filtered from the tidal data to remove noise from the input.

\section{Wind}

The wind data were obtained from National Weather Service for the Houston International Airport. A correlation with data collected in Galveston Bay at the same time allowed these data to be transferred to the Galveston Bay area.

\section{Salinity}

Gulf boundary salinities are based on 15-year monthly averages for the Gulf, and the work of Conchrane and Kelly (1986). 


\section{Results}

The maximum ebb for both conditions occurred at hour 416. Figures 11 and 12 show a zoomed-in view of the Texas City Ship Channel at this time for each condition. The maximum flood for both conditions occurred at hour 400.5. Figures 13 and 14 show a zoomed-in view of the Texas City Ship Channel at this time for both conditions.

Figures 15 and 16 show a contour plot of the difference in the velocity magnitude between the two grids at the maximum flood and ebb conditions, respectively. The difference was found by subtracting the velocity magnitudes for the base condition from the velocity magnitudes for the planned condition. For the flood conditions, the greatest difference occurred where the turning basin and berthing area were added. However, the approach to the Texas City Channel at Bolivar Roads showed a slight increase in current speed. The ebb conditions show a slight increase in current speed within the channel near the added berthing area, but a slight decrease in the currents in the berthing area. 


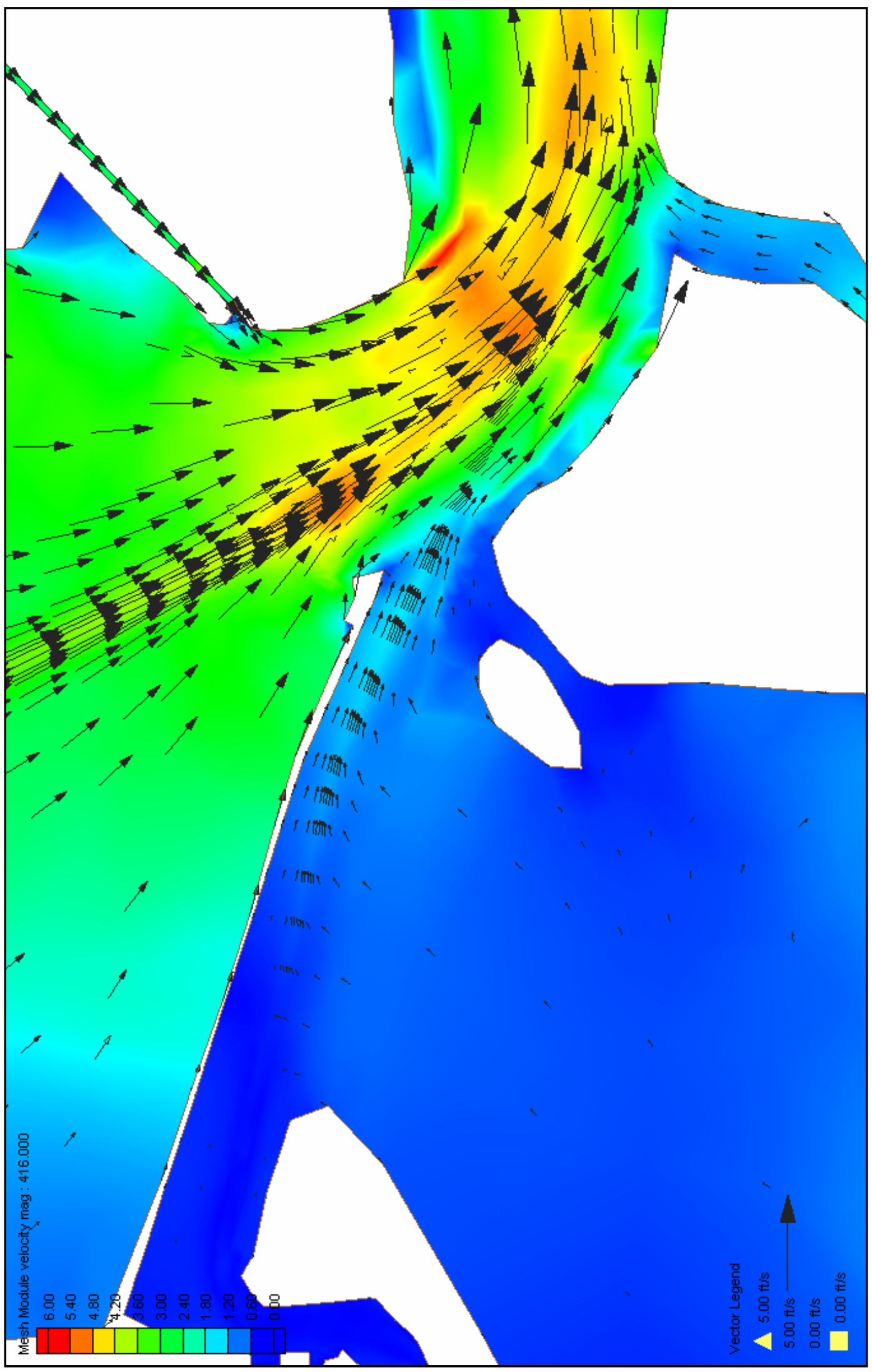

Figure 11. Maximum ebb for existing conditions 


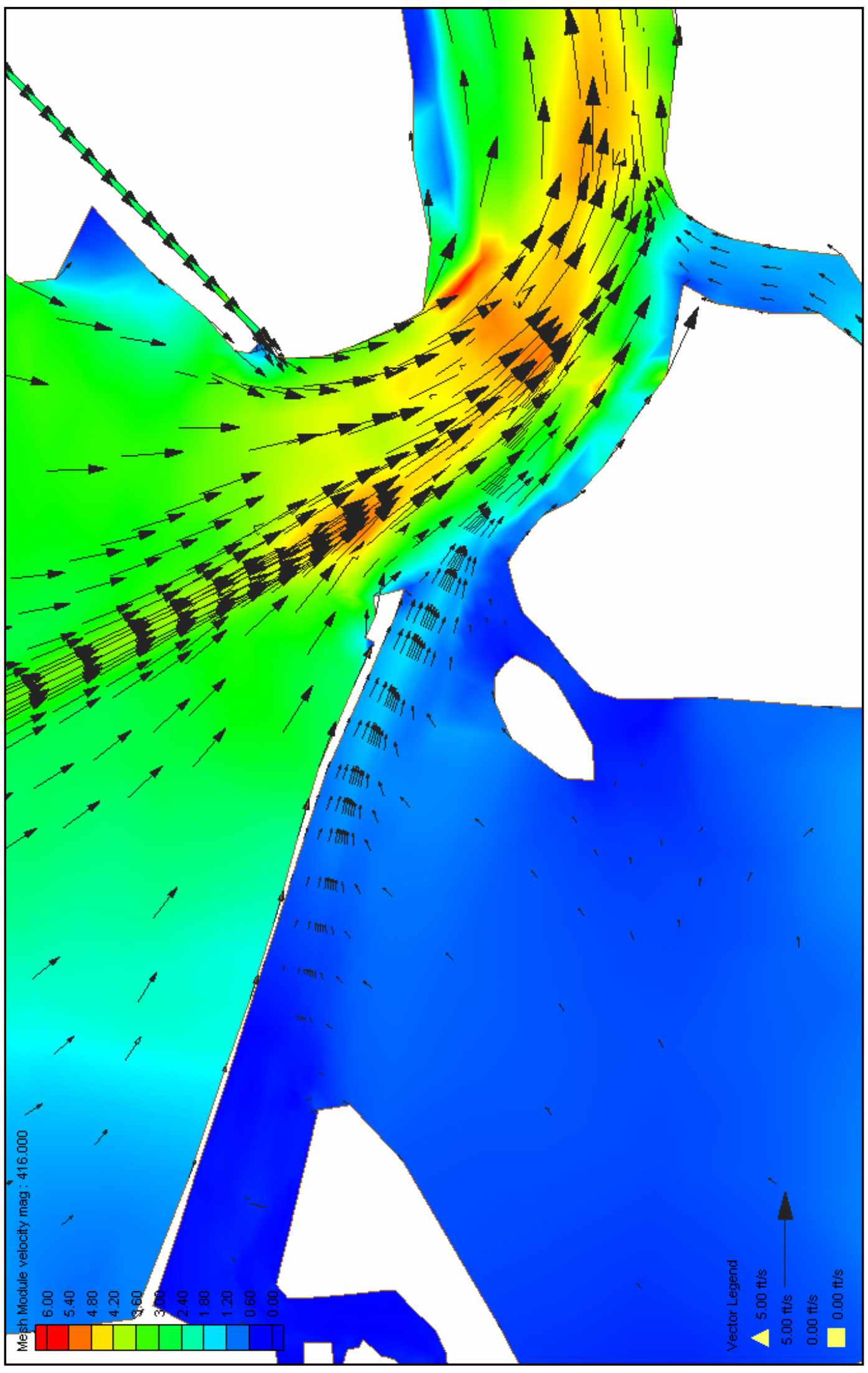

Figure 12. Maximum ebb for planned conditions 


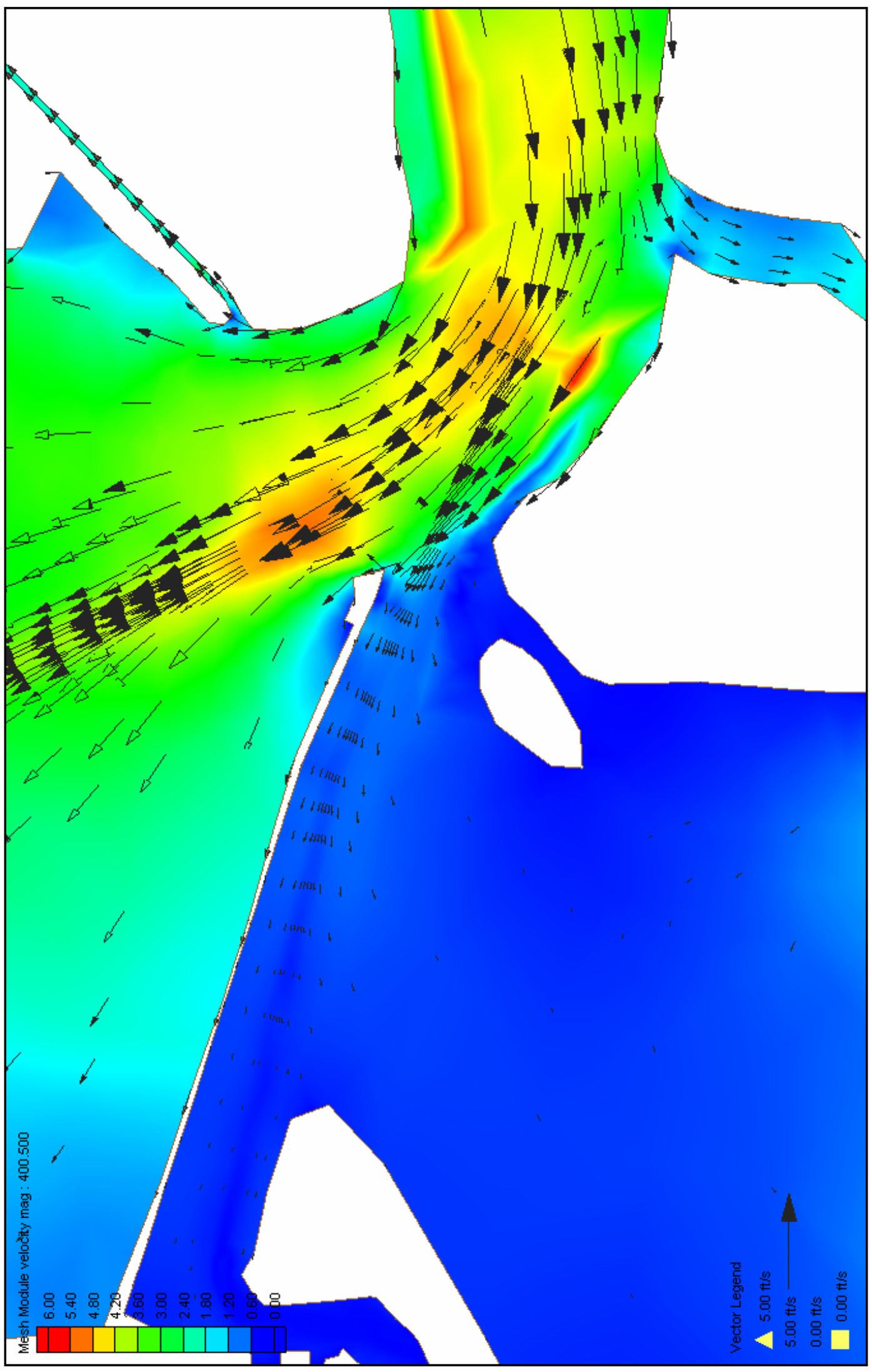

Figure 13. Maximum flood for existing conditions 


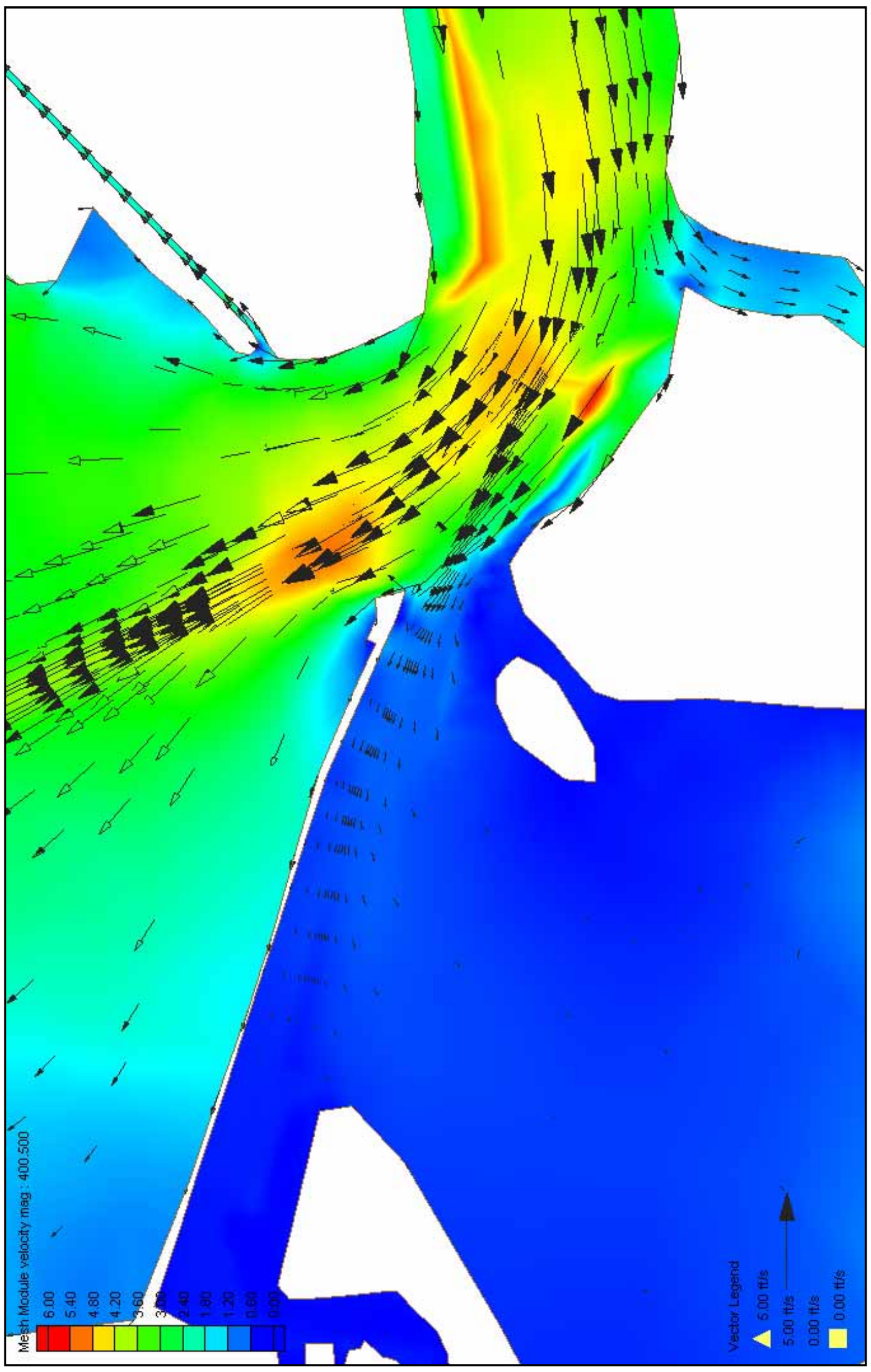

Figure 14. Maximum flood for planned conditions 


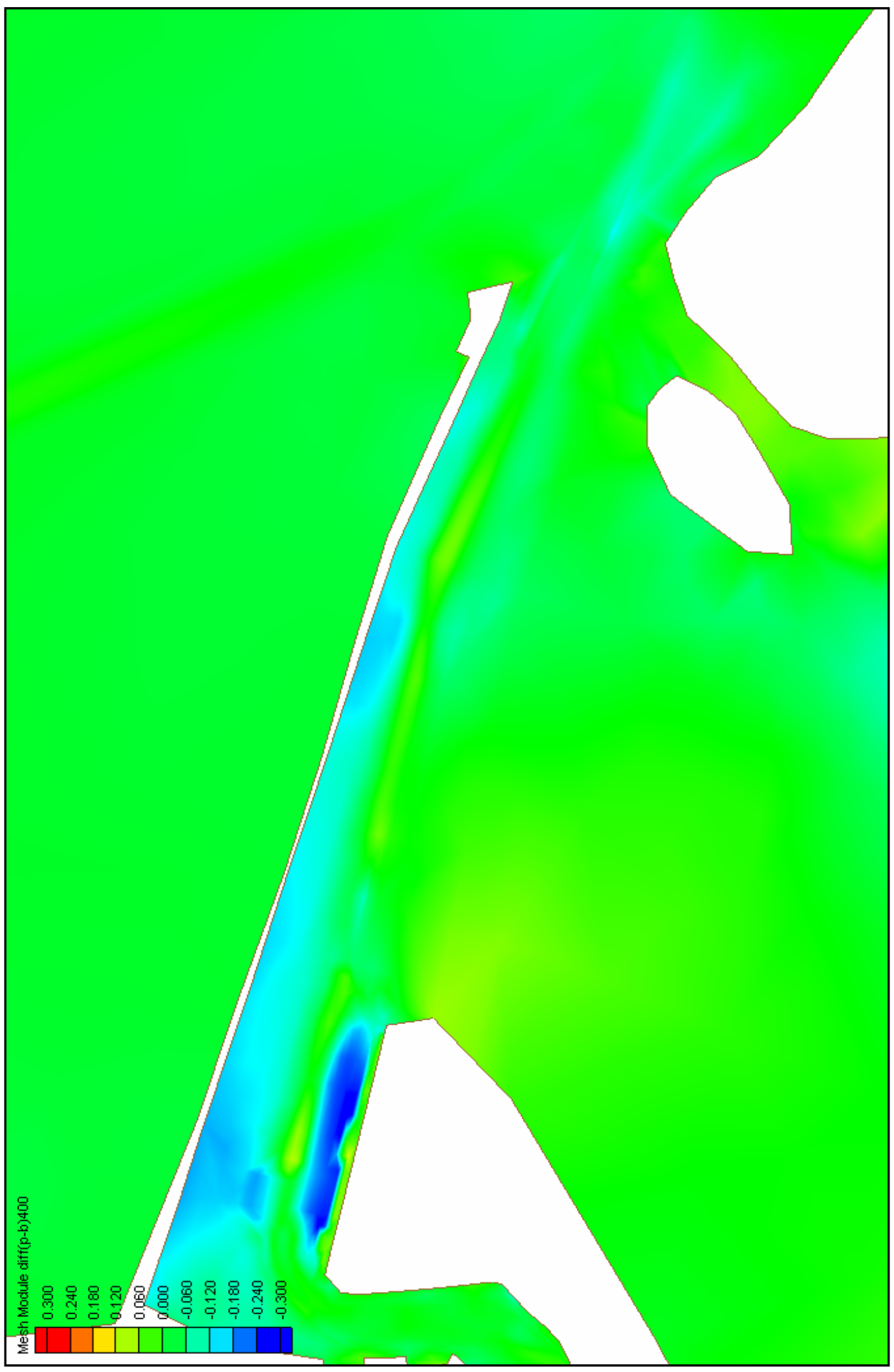

Figure 15. Difference (Plan-Base) in velocity magnitude at maximum flood conditions 


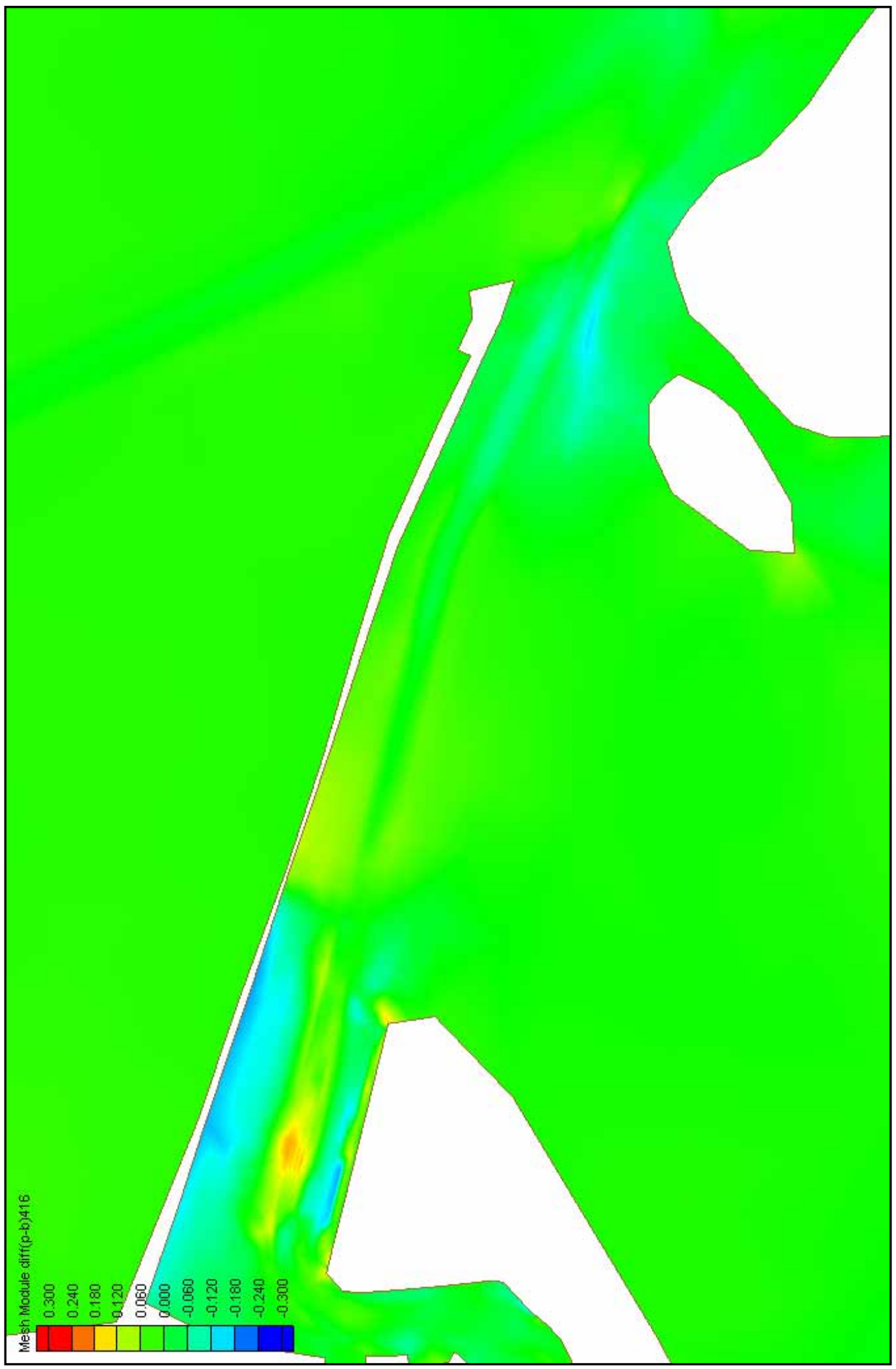

Figure 16. Difference (Plan-Base) in velocity magnitude at maximum ebb conditions 


\section{Summary and Conclusions}

The primary goal of this study was to provide currents for the ship simulator for maximum flood and ebb for both the existing and planned conditions. The following steps were performed to achieve this goal:

a. The mesh referred to as the "As Built" conditions used in the barge lanes study (Carrillo et al. 2002) was modified to fully include the Texas City Ship Channel.

$b$. A short check of the verification was done to ensure that the model was still behaving in the expected manner.

c. The Texas City Ship Channel was modified to reflect the planned conditions.

d. Each mesh was run for a month. The times of maximum flood and ebb were identified and the currents at these times were provided to the ship simulator.

Changes did not have a major effect on the maximum velocities at either the maximum flood or ebb conditions. The currents have been provided to the ship simulator for further analysis. 


\section{References}

Berger, R. C., McAdory, R. T., Martin, W. D., and Schmidt, J. H. (1995). "Houston-Galveston navigation channels, Texas Project; Report 3: Threedimensional hydrodynamics model verification,” Technical Report HL-92-7, U.S. Army Engineer Waterways Experiment Station, Vicksburg, MS.

Carrillo, A. R., Sarruff, M. S., and Berger, R. C. (2002). "Effects of adding barge lanes along Houston ship channel through Galveston Bay, Texas,” ERDC/CHL TR-02-23, U.S. Army Engineer Research and Development Center, Vicksburg, MS.

Cochrane, J. D., and Kelly, F. J. (1986). "Low-frequency circulation on the Texas-Louisiana continental shelf,” Journal of Geophysical Research 91(C9), 10645-10659. 


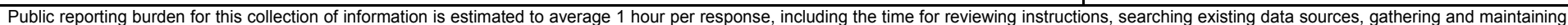

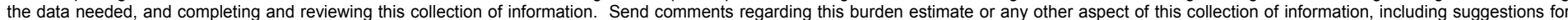

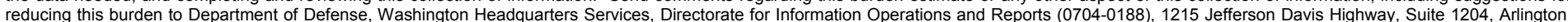

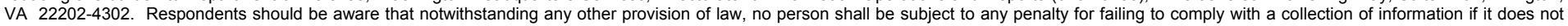
display a currently valid OMB control number. PLEASE DO NOT RETURN YOUR FORM TO THE ABOVE ADDRESS.

\begin{tabular}{l|c}
$\begin{array}{l}\text { 1. REPORT DATE (DD-MM-YYYY) } \\
\text { August } 2005\end{array}$ & $\begin{array}{c}\text { 2. REPORT TYPE } \\
\text { Final report }\end{array}$ \\
\hline
\end{tabular}

\section{TITLE AND SUBTITLE}

\begin{tabular}{|l|l} 
Texas City Ship Channel Deepening Study, Hydrodynamic Model & \\
\cline { 2 - 2 } & $5 \mathrm{c}$ \\
\hline
\end{tabular}

\begin{tabular}{|l|l} 
Texas City Ship Channel Deepening Study, Hydrodynamic Model & \\
\cline { 2 - 2 } & $5 \mathrm{c}$ \\
\hline
\end{tabular}

\section{AUTHOR(S)}

Lisa M. Lee, Jennifer N. Tate, R. C. Berger

\begin{tabular}{|l|l} 
3. DATES COVERED (From - To) \\
\hline 5a. CONTRACT NUMBER
\end{tabular}

5b. GRANT NUMBER

5c. PROGRAM ELEMENT NUMBER

5d. PROJECT NUMBER

5e. TASK NUMBER

5f. WORK UNIT NUMBER

7. PERFORMING ORGANIZATION NAME(S) AND ADDRESS(ES)

8. PERFORMING ORGANIZATION REPORT NUMBER

U.S. Army Engineer Research and Development Center

Coastal and Hydraulics Laboratory

ERDC/CHL TR-05-6

3909 Halls Ferry Road

Vicksburg, MS 39180-6199

\section{SPONSORING / MONITORING AGENCY NAME(S) AND ADDRESS(ES)}

U.S. Army Engineer District, Galveston

P.O. Box 1229

Galveston, TX 77553-1229

\section{DISTRIBUTION / AVAILABILITY STATEMENT}

Approved for public release; distribution is unlimited.

\section{SUPPLEMENTARY NOTES}

\section{ABSTRACT}

The U.S. Army Engineer District, Galveston (SWG), is proposing to deepen the Texas City Ship Channel as well as add a turning basin and berthing area. The Texas City Ship Channel is approximately 6.75 miles long and extends from Bolivar Roads at the entrance of Galveston Bay from the Gulf of Mexico to the turning basin at Texas City. The Houston Ship Channel and the Texas City Ship Channel provide access to the deep-water ports along the bay. The study area includes the entire bay area and these deep-draft channels. The Texas City Ship Channel is currently $40 \mathrm{ft}$ deep at mean low water ( $\mathrm{mlw}$ ) and $400 \mathrm{ft}$ wide. The proposed depth is $45 \mathrm{ft}$ and the width will remain the same. The added turning basin measures $700 \mathrm{ft}$ across the top, with the berthing area 6,000 by $825 \mathrm{ft}$. A ship simulator study is being conducted to assess the impact of these modifications on the ability of shipping to use the port. This particular study is used to determine and provide maximum ebb and flood currents for the ship simulator study.

\section{SUBJECT TERMS}

Channel deepening

Houston Ship Channel

16. SECURITY CLASSIFICATION OF:

a. REPORT

UNCLASSIFIED
Hydrodynamic model

Texas City Ship Channel

\begin{tabular}{|l|c|}
\hline $\begin{array}{l}\text { 17. LIMITATION } \\
\text { OF ABSTRACT }\end{array}$ & $\begin{array}{c}\text { 18. NUMBER } \\
\text { OF PAGES }\end{array}$ \\
\cline { 3 - 3 } & 28 \\
\end{tabular}

19a. NAME OF RESPONSIBLE PERSON

19b. TELEPHONE NUMBER (include area code) 